Carlos Foresti S.

\title{
La tensión en un cuento de Baldomero Lillo
}

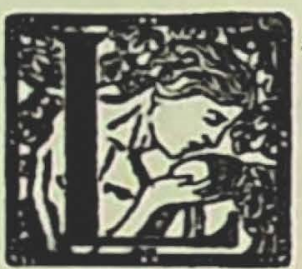

A TENSION sólo es posible a través de una secuencia temporal prudentemente elaborada. Lessing dejó en claro que la narración conforma su mundo en el dominio del tiempo y sólo incurre en tímidas invasiones del espacio si el escritor no desea prodigar su esfuerzo sin utilidad estética. Pero aunque todo relato se desarrolle en el tiempo, transcurre éste con la naturalidad de algo que se utiliza sin percibirlo. Hay oportunidades, sin embargo, en que cobra presencia y, entonces, su dimensión es otra, como en algunos cuentos de Baldomero Lillo donde es predominante y exclusivo elemento de la estructura narrativa. "Sub Sole", "El Pozo", "Sobre el abismo", son ejemplos de lo que afirmamos. En ellos juega un papel decisivo y su lento avance nos sobrecoge hasta la desesperación.

Analicemos "Sobre el Abismo".

Hay aquí dos modos de construcción temporal que a su vez marcan dos partes en el relato. La primera plantea el contenido argumental y su motivo, y la otra es un dilatado desenlace cuya justificación ha sido preparada desde las primeras líneas. "Celos" y "segundos" son las claves respectivas. 
Alrededor del sustantivo "celos" se puede construir un asunto, pero "segundos" nos enfrenta a una situación tensa o de espera. Y si se convierte en clave de un desenlace, el gradual avance del tiempo adquiere tono angustioso.

Los mineros se han reunido para apurar sus viandas. Un viejo es el blanco de las bromas de mal gusto y Rejis sale en su defensa. Aparecen los insultos y entre ellos una maliciosa intención de provocar celos en Rejis. La intención logra su efecto: el minero se desespera, necesita salir de la mina. Busca una justificación para sus jefes, pero el pretexto no aparece y decide entonces aprovechar la pasada del ascensor frente a una galería abandonada. Su plan está trazado: se cogerá de la baranda de la jaula cuando pase a nivel de la galería.

Hasta aquí la primera parte.

El tiempo ha pasado con naturalidad, pero tomará magnitud porque la narración está construida hacia el final y el desenlace cobra importancia como para desplazar asunto y motivo iniciales.

Desde el momento en que Rejis empieza su ascensión hasta el último movimiento de la jaula, transcurrirían dos minutos reales, pero Baldomero Lillo dilata los dos minutos y nos identifica con la angustia del hombre en el vacío.

El verbo aguardar prepara el camino a los sustantivos "segundos" o "instantes" y al adjetivo "lento", con cuya serie lingüística crece el tiempo ante nuestra vista.

Rejis está al acecho; espera la pasada del ascensor:

"Reteniendo la respiración "aguardó" con el corazón palpitante. Pasaron algunos "segundos" y una leve oscilación del cable le anunció que el momento de emprender el viaje aéreo había llegado. Asentó lo más sólidamente que pudo los pies en la saliente de la roca y alargó ambos brazos. No tuvo mucho que "aguardar". Surgiendo del abismo vislumbró de un modo con- 
fuso la techumbre del ascensor y bruscamente se echó adelante. Sus manos chocaron contra una superficie dura y lisa, resbalaron por ella un corto trecho y encontrando un obstáculo, hicieron presa de él. Instantáneamente se halló suspendido en el vacío envuelto en tinieblas impenetrables".

Pero el plan no ha resultado del todo. Ha calculado mal la velocidad de la máquina y sus dedos sólo han logrado aferrarse a la pestaña de un riel en el borde inferior de la jaula.

El tiempo transcurre más lento.

"En un "segundo" analizó Rejis su situación y con infinito espanto vio que era desesperada. Sobrecogido de terror, sus cabellos se le erizaron y la voz se le estranguló en la garganta. La conformación de aquella ranura le permitía introducir en ella las dos primeras falanges de sus crispados dedos. Toda la sangre se le agolpó al corazón cuando tras algunos "segundos", sintió que empezaban a resbalar sobre el metal a impulso de la violenta tracción de su cuerpo, balanceándose como un péndulo en el abismo. Lanzó un alarido hondo y penetrante estremeciéndose de angustia y de pavor. $Y$ bajo la terrible energía desarrollada por sus músculos, incrustóse en el duro hierro soldándose con él; y el ascensor llevando tras sí aquel vívido apéndice, continuó su marcha ascendente, "lenta" y uniforme, a lo largo del tubo vertical.

"Transcurrieron algunos "instantes" brevísimos y Rejis, que sentía zumbar la sangre en sus oídos y martillarle el corazón dentro del pecho, empezó a calcular mentalmente la distancia recorrida. ¿A qué altura se encontraba? ¿Cuántos metros faltarían aún para alcanzar el brocal? Con los dientes apretados, la faz convulsa, los ojos fuera de las órbitas, sacudido por espasmos de agonía y bañado en sudor frío parecíale una eternidad cada décimo de "segundos". 


\section{Mibliotoce \\ Mayir ll ins 3 .}

El tiempo no avanza. La ascensión es lenta, penosa, y los segundos se fraccionan, se prolongan, se estiran y el ascensor no llega, y...

"De súbito a su lado, tocándolo casi, el minero entrevió fugazmente algo informe que caía de lo alto como una piedra. Una luz viva lo deslumbró y le pareció distinguir un rostro pálido con dos grandes ojos muy abiertos, brillando siniestramente en la oscuridad. Las dos jaulas al cruzarse, sumando sus contrarias velocidades, señalaron el punto de contacto con un silbido característico, silbido que en el cerebro de Rejis retumbó como si los cuatro arcángeles del Apocalipsis le gritaran a la vez: ¡Estás en la mitad del camino! ¡Falta aún un minuto, es decir, un siglo para que el ascensor recorra los ciento cincuenta metros que te separan de la superficie donde está la vida, la salvación! ¡Cada "segundo" que pasa no hace sino que alargar el trayecto que en breve recorrerá tu cuerpo en su vertiginosa caf́da mortal!"

Sigue la ascensión y el pensamiento.

“¡No, no quería morir! Y a medida que el "instante” fatal se precipitaba, su espíritu adquiría una potencia de visión extraordinaria. Todos los acontecimientos de su vida desfilaron ante él en un "segundo".

Tenemos la vaga esperanza de que Rejis se salve, pero sus dedos se resbalan, siente que las yemas atraviesan el hierro y...

"Acto continuo estalló bajo su cráneo un trueno formidable y una tromba de viento le azotó el rostro y le cortó la iespiración..." 
El relato se suspende y el tiempo vuelve a su normalidad. A veinte centímetros de los pies, Rejis, sin saberlo, tenía una sólida plataforma de roble. Pero sobre ella hay...

"un obrero con la cabellera blanqueada a trechos, los ojos abiertos y las pupilas muy enormemente dilatadas, el cual jamás recobró la razón..."

Este es el relato.

Quien así maneja los elementos utilizados en una estructura narrativa no es sólo un escritor intuitivo. 